\title{
HUBUNGAN ANTARA KEPUASAN KERJA DENGAN KONFLIK PERAN GANDA PADA PERAWAT WANITA YANG SUDAH MENIKAH DI RUMAH SAKIT ISLAM SULTAN AGUNG SEMARANG
}

\author{
Sharah Mahdiatunnisa dan Abdurrohim \\ Fakultas Psikologi Universitas Islam Sultan Agung, Jl. Kaligawe Raya KM. 4, Kota Semarang 50112
}

Email : abdurrohim@unissula.ac.id

\begin{abstract}
Abstrak
Penelitian ini bertujuan untuk mengetahui hubungan antara konflik peran ganda dengan kepuasan kerja pada perawat wanita yang sudah menikah dan memiliki anak. Variabel tergantung dalam penelitian ini adalah konflik peran ganda dan variabel bebas kepuasan kerja. Penelitian ini menggunakan metode kuantitatif. Analisa dilakukan kepada 96 perawat wanita yang sudah menikah dan memiliki anak di Rumah Sakit Islam Sultan Agung Semarang. Metode pengambilan data dalam penelitian ini menggunakan skala konflik peran ganda dan skala kepuasan kerja. Skala konflik peran ganda berjumlah 36 aitem dengan rentang daya beda skala konflik peran ganda 0,361- 0,749 dan memiliki koefisien reliabilitas sebesar 0,925. Skala kepuasan kerja berjumlah 30 aitem dengan rentan daya beda skala kepuasan kerja 0,316-0,630 dan memiliki koefisien reliabilitas sebesar 0,867. Analisa data dalam penelitian ini mengguanakan teknik korelasi product moment dari Pearson. Berdasarkan analisa product moment diperoleh nilay $r_{x y}$ sebesar $-0,202$ dengan taraf signifikansi $p=0,024(p<0,05)$. Hasil ini menunjukkan terdapat hubungan negatif yang signifikan antara konflik peran ganda dengan kepuasan kerja pada perawat wanita yang sudah menikah dan memiliki anak.
\end{abstract}

Kata kunci: konflik peran ganda, kepuasan kerja

\section{RELATIONSHIP BETWEEN JOB SATISFACTION AND WORK-FAMILY CONFLICT AMONG MARRIED FEMALE NURSES AT SULTAN AGUNG ISLAMIC HOSPITAL}

\begin{abstract}
This research aimed to determine the correlation between work satisfaction and work family conflict in Sultan Agung Islamic Hospital. The dependent variable was work family conflict and the independent variable was work satisfaction. This research used quantitative method. The samples analysis was of 96 nurse who is married and has child in Sultan Agung Islamic Hospital. The data collection of this study used to method family work conflict scale and work satisfaction scale. Work family conflict scale is consisted of 36 items with item-total correlation $0,361-0,749$ and reliability 0,925. The scale of work satisfaction amounted 30 items with item total correlation $0,316-0,630$ and reliability 0,867. In this research, the data analysis used bivariate correlation from Pearson. Based on the results of product moment analysis obtained $r_{x y}=-0,202$ with significance level $P=0,024(P<0,05)$. The result showed that there was a significant negative relationship between work family conflict and work satisfaction in Sultan Agung Islamic Hospital.
\end{abstract}

Keywords: work family conflict, work satisfaction 
Hubungan Antara Kepuasan Kerja dengan Konflik Peran Ganda Pada Perawat Wanita yang Sudah Menikah di Rumah Sakit Islam Sultan Agung Semarang

Vol. 15 (1) 2020, 78-87

\section{Pendahuluan}

Tempat pelayanan kesehatan masyarakat merupakan tempat terpenting untuk masyarakat yang membutuhkan pelayanan kesehatan.Kesehatan adalah aset paling penting yang dimiliki manusia sehingga manusia membutuhkan pelayanan kesehatan. Pelayanan kesehatan merupakan hak-hak yang harus didapatkan oleh masyarakat karena sudah tertulis dalam Undang-Undang nomor 23 tahun 1992. Undang-Undang nomor 23 tahun 1992 menjelaskan tentang kesehatan dan hak-hak dalam mendapatkan jaminan kesehatan bagi warga negara Indonesia.Salah satu tempat untuk mendapatkan pelayanan kesehatan adalah rumah sakit.

Perawat merupakan salah satu sumber daya terpenting dalam rumah sakit.Tugas penting perawat yaitu memberikan pelayanan dan merawat pasien selama 24jam. Berdasarkan data Badan Pengembangan Dan Pemberdayaan Sumber Daya Manusia Kesehatan (BPPSDMK) total sumber daya manusia kesehatan pada tahun 2017 sebanyak 1.143.494 sedangkan tenaga kesehatan terdiri dari 836.466. Tenaga kesehatan sebanyak $(73,15 \%)$ tenaga penunjang kesehatan sebanyak $(26,85 \%)$ dan tenaga kesehatan terbanyak yaitu keperawatan sebanyak (30,19\%) (Budijanto, 2018). Almasitoh (2011) menyatakan bahwa perawat merupakan pekerjaan yang banyak diminati oleh wanita.

Bagi perawat wanita yang sudah menikah harus bisa mengatur waktu bekerja dan mengurus kebutuhan rumah tangga. Wanita yang sudah menikah dan memutuskan untuk bekerja cenderung akan mengalami konflik peran ganda. Ruslina (2014) mengatakan bahwa konflik adalah suatu proses dimana terjadi pertentangan dari suatu pemikiran dan akan membawa suatu pengaruh yang negatif. Santrock (2002) menyatakan bahwa konflik peran adalah suatu gambaran tentang pernikahan yang didalamnya terdapat pasangan suami istri yang mempunyai pekerjaan di tempat mereka berkarier. Sedangkan Greenhaus \& Beutell, (1985) menyatakan bahwa konflik peran ganda adalah munculnya konflik dikarenakan tekanan-tekanan antara pekerjaan dan keluarga. Suryadi dkk (Indriani \& Sugiasih, 2016) berpendapat bahwa konflik peran adalah konflik yang timbul karena adanya lebih dari satu peran dalam satu waktu yang berakibat negatif bagi diri sendiri dan bagi lingkungan keluarga.

Luthans (Triono \& Prayitno, 2017) menyatakan bahwa individu yang mengalami konflik peran adalah individu yang memiliki lebih dari satu peran yang harus dijalankan dalam waktu yang bersamaan. Seseorang yang memiliki lebih dari satu peran akan memiliki waktu yang terbatas maka dari itu harus dapat membagi waktu dengan baik antara peran satu dengan peran yang lainnya. Jimenez dkk (dalam Mayasari, 2014) juga berpendapat bahwa ketidaksejajaran antara keluarga dan pekerjaan dapat disebut dengan konflik peran. Menjadi seorang ibu rumah tangga dan menjadi wanita karier kemungkinan besar terjadi konflik peran.

Apollo \& Cahyadi (2012) menyatakan bahwa konflik peran ganda terdiri dari 6 (enam) aspek, yaitu pertama pengasuhan anak. Wanita yang mengalami konflik peran ganda cenderung mencemaskan kesehatan anak, perhatian terhadap anak, kondisi emosi anak, dan pendidikan anak. Kedua, bantuan pekerjaan rumah tangga adalah wanita memiliki dua peran cenderung membutuhkan bantuan untuk mengurus rumah tangga (suami, pembantu rumah tangga, saudara jauh). Ketiga, Interaksi bersama anak dan suami. Wanita yang mengalami konflik peran ganda dipengaruhi oleh cara komunikasi dalam keluarganya, untuk mengungkapkan keinginan, kebutuhan, keluhan dsb. Keempat, waktu untuk keluarga. Wanita dengan dua peran sekaligus sering merasa kekurangan waktu dengan suami, anakanak dan untuk dirinya sendiri. Kelima, penentuan prioritas. Apabila sesorang mengalami konflik peran ganda akan cenderung mengalami kebingungan dalam menentukan prioritas antara perkerjaan dan keluarga. Sehingga hal tersebut akan menimbulkan permasalahan dalam diri individu. Terakhir, tekanan 
karir dan tekanan keluarga adalah wanita yang bekerja memiliki tanggung jawab tersendiri dalam pekerjaannya. Tidak jarang hal tersebut membuat beban dan tekanan untuk individu tersebut. Di sisi lain, tugas sebagai seorang ibu yang mengharuskan untuk mengurus urusan rumah tangga dan anggota keluarga membuat wanita dengan peran ganda memiliki tekanan dalam hidupnya.

Konflik peran ini juga terjadi pada perawat wanita di Rumah Sakit Islam Sultan Agung Semarang yang sudah berumah tangga. Berdasarkan wawancara yang telah dilakukan dengan 2 perawat RS Islam Sultan Agung Semarang dapat disimpulkan bahwa peneliti menemukan suatu permasalahan yang terjadi pada Perawat RS Islam Sultan Agung Semarang memiliki konflik peran ganda. Perawat cenderung memiliki tekanan karir dan keluarga saat memutuskan meninggalkan anak untuk bekerja memenuhi kewajibannya sebagai seorang pekerja. Salah satu faktor dari seorang yang mengalami konflik peran ganda adalah kepuasan kerja.

Hasibuan (2009) mengatakan kepuasan kerja di dalam perusahaan adalah bagaimana seorang karyawan memperoleh pujian dari hasil pekerjaan yang sudah dikerjakan, penempatan atau jabatan yang diberikan, bagimana seorang atasan memperlakukan bawahannya, peralatan yang menujang pekerjan, dan suasana lingkungan pekerjaan mendukung yang baik bagi karyawan. Sedangkan Wagner III \& Holenbeck (Dhania, 2010) berpendapat bahwa kepuasan kerja adalah perasaan menyenangkan yang muncul dari perasaan dan akan membuat presepsi mengenai suatu pekerjaan itu sendiri. Setiap individu memiliki kepuasan kerja yang berbeda-beda dan mempunyai caranya masing-masing agar dapat meningkatkan kepuasan kerjanya. Kepuasan kerja dapat meningkatkan loyalitas pada perusahaan karena semakin tinggi kepuasan seorang pegawai maka akan semakin tinggi dedikasi yang diberikan pegawai pada perusahaan. Perusahaan sebaiknya memberikan fasilitas-fasilitas yang dapat meningkat kepuasan kerja karyawan.

Kaswan (2015) berpendapat bahwa ada beberapa faktor yang akan mempengaruhi kepuasan karyawan. Hal itu adalah tingkat gaji dan tunjangan, promosi, kondisi saat bekerja, kepemimpinan dan bagaimana hubungan sosial karyawan itu sendiri. Mathis (2014) menyatakan bahwa ada dua alasan mengapa perusahaan harus memperhatikan kepuasan kerja karyawan karena banyak penelitian yang mengungkap bahwa kepuasan kerja karyawan dapat mempengaruhi komitmen kerja karyawan dan dapat mempengaruhi kinerja karyawan jika karyawan bekerja dengan baik maka akan berpengaruh pada kemajuan sebuah perusahaan dan karyawan yang kurang puas dalam kerjanya akan mempengaruhi komitmen organisasinya dapat dilihat dari ketidakhadiran dan keluar masuk.

Smith, Kendall \& Hulin (Luthans, 2006) berpendapat bahwa kepuasan kerja dapat dilihat dari persepsi seseorang terhadap 5 (lima) aspek berikut, yaitu pekerjaan itu sendiri (work itself), atasan, teman kerja, promosi dan gaji atau upah. Pertama, dalam suatu pekerjaan tentunya membutuhkan keahlian didalam masing-masing bidang. Sulit dan ringannya pekerjaan hanya karyawan itu sendiri yang dapat menilainya. Untuk meningkatkan kepuasan kerja tentunya seorang karyawan memerlukan kecocokan agar dapat bekerja dengan baik. Kedua, seorang atasan adalah contoh dan panutan bagi bawahannya. Atasan yang baik adalah atasan yang dapat mengayomi dan berperilaku baik terhadap bawahannya. Ketiga, teman kerja (workers). Teman kerja dapat membantu dan salah satu orang yang akan bekerja sama dalam menjalankan pekerjaan. Keempat, promosi yang dilakukan perusahaan tentunya akan memberikan kesempatan kepada karyawan agar mampu meningkatkan karier. Peningkatan karier tentunya akan meningkatkan kepuasan kerja terhadap karyawan. Terakhir, gaji atau upah (pay) untuk memenuhi kebutuhan seorang karyawan. Upah yang diberikan perusahaan terhadap karyawan sebanding atau tidak dengan pekerjaan yang telah karyawan lakukan. 
Hubungan Antara Kepuasan Kerja dengan Konflik Peran Ganda Pada Perawat Wanita yang Sudah Menikah di Rumah Sakit Islam Sultan Agung Semarang Vol. 15 (1) 2020, 78-87

Yousef (Churiyah, 2011) berpendapat bahwa seseorang yang mengalami konflik peran ganda tinggi maka akan mengalami stres yang akan mempengaruhi pekerjaan dan cenderung lebih kurang puas dalam pekerjaannya. Filley dan House (Wexley \& Yuki, 1992) juga menyimpulkan bahwa karyawan yang memiliki konflik peran akan berdampak pada pekerjaan. Seorang yang mengalami rendahnya kepuasan kerja maka akan berpengaruh dengan kinerjanya dan cenderung akan tidak dapat berkonsentrasi penuh kepada pekerjaannya. Kussuyarsana dan Soepatini (2008) dalam penelitiannya menggungkapkan bahwa konflik peran ganda berpengaruh negatif terhadap kepuasan kerja. Rantika \& Sunjoyo (2011) menguji pengaruh konflik peran ganda berpengaruh terhadap komitmen organisasional dengan kepuasan kerja sebagai mediasi, menunjukan hasil bahwa konflik peran ganda yang terdiri dari work interfering with the family and interfering with work berpengaruh signifikan terhadap kepuasan kerja.

Tujuan penelitian ini adalah untuk mengetahui apakah terdapat hubungan antara kepuasan kerja dengan konflik peran ganda pada perawat wanita yang sudah menikah. Manfaat teoritis dari penelitian ini yakni dapat memberikan kontribusi dalam dunia kerja sebagai ilmu pengetahuan khususnya dalam bidang organisasi yang mengkaji tentang pengaruh kepuasan kerja terhadap konflik peran ganda pada perawat wanita yang sudah menikah. Secara praktis, penelitian ini juga bermanfaat dalam memberikan informasi tentang seberapa besar pengaruh hubungan antara kepuasan kerja dengan konflik peran ganda pada perawat wanita yang sudah menikah.

\section{Metode Penelitian}

Seperti yang telah dipaparkan di paragraf sebelumnya, penelitian ini bertujuan untuk mengetahui hubungan kepuasan kerja dengan konflik peran ganda pada perawat wanita yang sudah menikah di Rumah Sakit Islam Sultan Agung Semarang. Variabel tergantung dalam penelitian ini adalah konflik peran ganda dan variabel bebas pada penelitian ini adalah kepuasan kerja. Penelitian ini menggunakan metode kuantitatif korelasional. Populasi dalam penelitian ini berjumlah 493 perawat Rumah Sakit Islam Sultan Agung Semarang. Penentuan sampel menggunakan teknik purposive sampling dengan kriteria subjek yakni perawat perempuan, sudah menikah dan memiliki anak. Dari hasil teknik sampling tersebut, diperoleh 113 subjek dengan rincian sebagai berikut:

Tabel 1. Sampel Penelitian

\begin{tabular}{clc}
\hline No & \multicolumn{1}{c}{ Nama Ruangan } & Jumlah \\
\hline 1 & Baitussalam 1 & 2 \\
2 & Baitussalam 2 & 6 \\
3 & Baitun Izah 1 & 11 \\
4 & Baitun Izah 2 & 12 \\
5 & Baitun Nisa 1 & 6 \\
6 & Baitun Nisa 2 & 7 \\
7 & Baitus Syfa & 11 \\
8 & Baitun Ma'ruf & 9 \\
9 & Athfal & 12 \\
10 & Na'im & 2 \\
11 & Baitur rijal & 7 \\
12 & ICU & 2 \\
13 & IGD & 14 \\
14 & Pristi & 7 \\
\hline
\end{tabular}


Metode pengambilan data menggunakan skala, yang mana pengumpulan data dilakukan dengan cara membuat pernyataan tertulis yang diajukan oleh responden mengenai hal yang disajikan dalam bentuk daftar pernyataan. Alat ukur yang digunakan dalam penelitian ini terdiri dari dua skala yakni skala konflik peran ganda dan skala kepuasan kerja. Kedua skala tersebut merupakan skala likert dengan menggunakan skala subjek yang terdiri dari 4 pilihan jawaban yaitu, Sangat Setuju (SS), Setuju (S), Tidak Setuju (TS), dan Sangat Tidak Setuju (STS). Setiap item memiliki dua jenis pernyataan, yaitu favourable dan unfavourable.

Variabel kepuasan kerja diukur menggunakan aspek kepuasan kerja menurut Smith, Kendall \& Hulin (Luthans, 2006), yaitu pekerjaan itu sendiri (work itself), atasan (supervisi), teman kerja (workers), promosi (pomotion), gaji (pay). Skala kepuasan kerja terdiri dari 22 aitem berdaya beda tinggi dengan koefisien berkisar antara 0,316-0,63. Skala ini memiliki nilai reliabilitas sebesar 0,867.

Pengukuran konflik peran ganda subjek diukur menggunakan skala konflik peran ganda berdasarkan aspek Apollo \& Cahyadi (2012), yakni pengasuhan anak, bantuan pekerjaan rumah tangga, waktu untuk keluarga, komunikasi dan interaksi dengan anak dan suami, menentukan prioritas, tekanan karier dan tekanan keluarga. Skala ini terdiri dari 27 aitem berdaya beda tinggi dengan koefisien berkisar 0,361-0,749 serta nilai reliabilitas alat ukur sebesar 0,925.

Tabel 2. Indeks Validitas dan Reliabilitas Alat Ukur Penelitian

\begin{tabular}{llll}
\hline \multirow{2}{*}{ Alat Ukur } & Jumlah Item & Indeks & Indeks \\
& Valid & Daya Beda Aitem & Reliabilitas \\
\hline Kepuasan Kerja & 22 & $0,316-0,63$ & 0,867 \\
Konflik Peran Ganda & 27 & $0,361-0,749$ & 0,925 \\
\hline
\end{tabular}

Data yang diperoleh akan dianalisis menggunakan teknik korelasi product moment dari Karl Pearson. Teknik ini digunakan untuk mengetahui hubungan antara dua variabel yang masing-masing variabel datanya berwujud skor serta menggambarkan hubungan antara dua gejala interval. Perhitungan dilakukan dengan menggunakan bantuan program SPSS (Statistical Product and Service Solution) for Windows Release Versi 22.0.

\section{Hasil}

Sebelum melakukan uji hipotesis, perlu dilakukan adanya uji asumsi terlebih dahulu. Uji asumsi dalam penelitian ini terdiri dari uji normalitas dan linieritas. Berdasarkan hasil uji normalitas yang telah dilakukan, diketahui bahwa data yang diperoleh dari skala konflik peran ganda mempunyai nilai K-SZ sebesar 0,114 dengan taraf signifikansi 0,004 $(p<0,05)$. Hasil ini menunjukan bahwa data dari skala konflik peran ganda termasuk penyebaran data yang tidak normal. Sedangkan uji normalitas pada skala kepuasan kerja menunjukan bahwa nilai K-SZ sebesar 0,195 dengan taraf signifikasi 0,000 ( $p<0,05)$. Hasil ini menjelaskan bahwa data dari skala kepuasan kerja merupakan penyebaran data yang tidak normal.

Tabel 3. Hasil Analisis Uji Normalitas

\begin{tabular}{lcccccc}
\hline \multicolumn{1}{c}{ Variabel } & Mean & Std Deviasi & KS-Z & Sig & $\mathbf{p}$ & Keterangan \\
\hline Konflik peran ganda & 81,979 & 13,609 & 0,114 & 0,004 & $<0,05$ & Tidak Normal \\
Kepuasan kerja & 66,541 & 7,704 & 0,195 & 0,000 & $<0,05$ & Tidak Normal \\
\hline
\end{tabular}


Hubungan Antara Kepuasan Kerja dengan Konflik Peran Ganda Pada Perawat Wanita yang Sudah Menikah di Rumah Sakit Islam Sultan Agung Semarang Vol. 15 (1) 2020, 78-87

Uji linieritas memiliki tujuan untuk menemukan apakah antar variabel memiliki korelasi yang berupa linier. Teknik yang tepat digunakan untuk menguji linieritas pada penelitian ini menggunakan uji F. Hasil uji linieritas antara variabel prokrastinasi akademik dengan variabel konflik peran ganda diperoleh nilai $F_{\text {linier }}$ sebesar 3,997 dengan taraf signifikan $p=0,048(p<0,05)$. Hasil uji linieritas menunjukan bahwa antara variabel konflik peran ganda dengan variabel kepuasan kerja memiliki hubungan yang linier.

Tabel 4. Hasil Uji Linieritas

\begin{tabular}{cccccc}
\hline & Sum of Squares & df & Mean Square & F & Sig. \\
\hline Regression & 717,718 & 1 & 717,718 & 3,997 &, 048 \\
Residual & 16878,241 & 94 & 179,556 & & \\
Total & 17595,958 & 95 & & & \\
\hline
\end{tabular}

The independent variable is kepuasan kerja

Berdasarkan hasil penelitian yang telah dilakukan, dapat diketahui bahwa kepuasan kerja pada perawat wanita yang sudah menikah berada ditingkat tinggi. Hal tersebut dapat diketahui dari jumlah responden yang terdapat didalam analisis deskriptif, dapat dilihat bahwa tingkat kepuasan kerja dengan kategori sangat tinggi memiliki 21 subjek dengan presentase 22\%, kategori tinggi memiliki 46 subjek dengan presentase $58 \%$, kategori sedang 29 subjek dengan presentasi $20 \%$, kategori rendah dan sangat rendah memiliki persentase $0 \%$.

Gambar 1. Kategorisasi skor skala konflik peran ganda

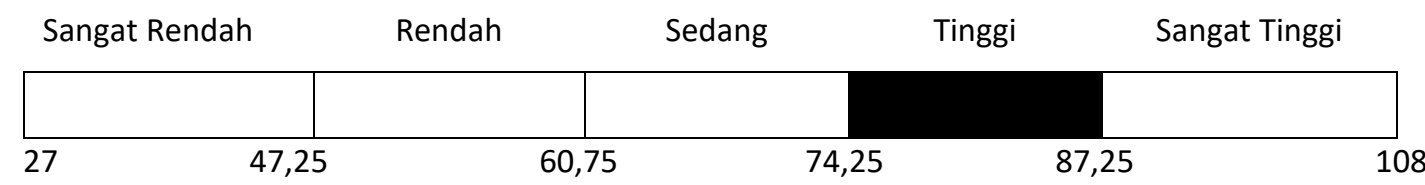

Gambar 2. Kategorisasi skor skala kepuasan kerja

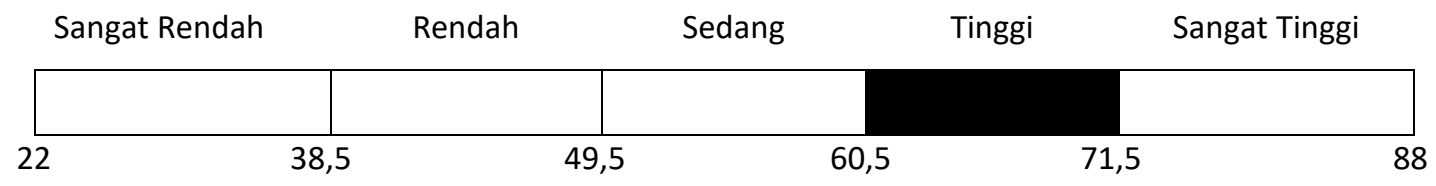

Berdasarkan gambar pemetaan kategorisasi subjek berdasarkan skala konflik peran ganda dan kepuasan kerja, dapat dilihat dari skor mean empirik konflik peran ganda yaitu 66,56 yang berada pada kategori tinggi. Subjek yang memiliki konflik peran ganda sangat tinggi berjumlah 27 dengan persentase $28 \%$, kategori tinggi 40 dengan persentase $42 \%$, kategori sedang sebesar $28 \%$ dengan jumlah subjek sebanyak 27 . Kemudian kategori rendah mempunyai persentase sebesar $2 \%$ dengan jumlah subjek 2. Sedangkan kategori sangat rendah memiliki persentase $0 \%$. Hasil analisis dalam penelitian ini menunjukan bahwa hipotesis yang peneliti ajukan diterima, yaitu dimungkinkan terdapat hubungan negatif yang signifikan antara konflik peran ganda dengan kepuasan kerja. Semakin tinggi kepuasan kerja seseorang, semakin rendah konflik peran ganda yang dialami. Besarnya persentase variabel konflik peran ganda mempengaruhi kepuasan kerja pada perawat wanita yang sudah menikah.

Tahap menguji hipotesis adalah tahap yang dilakukan setelah tahap uji asumsi. Penelitian ini menggunakan teknik korelasi Product Moment yang digunakan untuk melihat apakah terdapat hubungan negatif terhadap konflik peran ganda dengan kepuasan kerja pada perawat wanita yang 
sudah menikah di Rumah Sakit Islam Sultan Agung Semarang. Hasil uji korelasi menunjukan hasil nilai kolerasi antara variabel yang sebelumnya diuji $r_{x y}=-0,202$ dengan taraf signifikansi $p=0,024(p<0,05)$. Hasil menunjukan bahwa terdapat hubungan negatif yang signifikan antara konflik peran ganda dengan kepuasan kerja pada perawat yang sudah menikah di Rumah Sakit Islam Sultan Agung Semarang. Hasil menunjukan bahwa semakin tinggi konflik peran ganda semakin rendah kepuasan kerja atau apabila semakin rendah konflik peran ganda semakin tinggi kepuasan kerja. Hasil tersebut menandakan bahwa hipotesis dalam penelitian ini diterima.

Tabel 5. Hasil Uji Korelasi Product Moment Pearson

\begin{tabular}{cccc}
\multicolumn{4}{c}{ Correlations } \\
\hline Pearson Correlation & konflik_peran_ganda & konflik_peran_ganda & kepuasan_kerja \\
& kepuasan_kerja & 1,000 &,- 202 \\
Sig. (1-tailed) & konflik_peran_ganda &,- 202 & 1,000 \\
& kepuasan_kerja &. &, 024 \\
N & konflik_peran_ganda &, 024 &. \\
& kepuasan_kerja & 96 & 96 \\
\hline
\end{tabular}

\section{Pembahasan}

Tujuan dari penelitian ini yaitu untuk mengetahui apakah ada hubungan antara konflik peran ganda dengan kepuasan kerja perawat wanita yang sudah menikah di Rumah Sakit Islam Sultan Agung Semarang. Penelitian ini menggunakan teknik korelasi Pearson Product Moment dan hasil menunjukkan bahwa korelasi antara konflik peran ganda dengan kepuasan kerja memperoleh hasil $r_{x y}$ $=-0,202$ dengan taraf signifikan $0,024(p<0,05)$. Hasil ini menunjukkan bahwa terdapat hubungan negatif antara konflik peran ganda dengan kepuasan kerja pada perawat wanita yang sudah menikah di Rumah Sakit Islam Sultan Agung Semarang. Hal ini menjelaskan bahwa semakin positif konflik peran ganda, maka semakin rendah kepuasan kerja dan semakin negatif konflik peran ganda maka semakin tinggi kepuasan kerja. Konflik peran ganda telah memberikan sumbangan efektif $4,1 \%$ kepada variabel kepuasan kerja, yang berdasarkan R squared sebesar 0,041. Sedangkan sebesar 95,9\% konflik peran ganda dapat dipengaruhi oleh faktor lain yang tidak diteliti.

Berdasarkan hasil uji normalitas yang telah dilakukan, penelitian ini diketahui bahwa skala konflik peran ganda mempunyai nilai K-SZ sebesar 0,114 dengan taraf signifikan 0,004 $(p<0,05)$. Hasil ini menunjukkan bahwa data skala konflik peran ganda termasuk penyebaran data yang tidak normal. Sedangkan uji normalitas pada skala kepuasan kerja menunjukan bahwa nilai K-SZ dengan taraf signifikansi sebesar 0,195 dengan taraf signifikasi 0,000 $(p<0,05)$. Hasil ini menjelaskan bahwa data dari skala kepuasan kerja termasuk penyebaran data yang tidak normal. Namun menurut distribusi data yang tidak normal menurut Azwar (2000) walaupun data yang digunakan tidak sesuai dengan asumsiasumsinya, namun analisis tetap dapat dilakukan tanpa harus melakukan pemeriksaan terlebih dahulu terhadap terpenuhinya atau tidaknya asumsi yang bersangkutan. Maka kesimpulan hasil analisisnya tidak selalu invalid. Glass, dkk (dalam Hinkle, 1979) mengatakan bahwa apabila populasi-populasi sampel tidak normal maka efek kesalahan generalisasinya kecil.

Hasil penelitian ini juga diperkuat dengan hasil penelitian yang pernah dilakukan sebelumnya oleh Agustina (2009) yaitu penelitian yang membahas mengenai hubungan antara pengaruh konflik peran, ketidak jelasan peran, dan kelebihan peran terhadap kepuasan kerja dan kinerja auditor. Hasil penelitian menunjukan bahwa terdapat hubungan negatif yang signifikan antara konflik peran ganda 
Hubungan Antara Kepuasan Kerja dengan Konflik Peran Ganda Pada Perawat Wanita yang Sudah Menikah di Rumah Sakit Islam Sultan Agung Semarang Vol. 15 (1) 2020, 78-87

dengan kepuasan kerja. Hal tersebut dibuktikan dengan nilai $r_{x y}-5,499$ dengan signifikansi 1,662. Kemudian penelitian lain dari Laksmi (2012) yang meneliti hubungan antara konflik peran ganda dengan kepuasan kerja bagi karyawati bagian produksi PT X. Uji hipotesis pada variabel konflik peran ganda dengan kepuasan kerja memiliki koefisien korelasi $-0,274$ dengan signifikansi $p=0,045(p<0,05)$. Hasil tersebut menunjukan bahwa ada hubungan negatif secara signifikan antara konflik peran ganda dengan kepuasan kerja korelasi yang signifikan antara konflik peran ganda dengan kepuasan kerja pada karyawati bagian produksi PT.X.

\section{Kesimpulan}

Hasil penelitian ini menunjukan bahwa terdapat hubungan negatif yang signifikan antara konflik peran ganda dengan kepuasan kerja perawat wanita yang sudah menikah dan memiliki anak di Rumah Sakit Islam Sultan Agung Semarang. Nilai koefisien korelasi sebesar $r_{x y}=-0,024$ dengan signifikansi $p=$ $0,024(p<0,05)$. Dimungkinkan terdapat hubungan yang signifikan antara konflik peran ganda dengan kepuasan kerja pada perawat wanita yang sudah menikah dan memiliki anak di Rumah Sakit Islam Sultan Agung Semarang. Konflik peran ganda telah memberikan sumbangan efektif sebesar 4,1\% yang dapat dilihat dari R square $=0,041$, kemudian sumbangan efektif sebesar $95,9 \%$ dipengaruhi faktor lain, baik dari faktor individu maupun faktor di luar individu.

\section{Daftar Pustaka}

Adams, G. A., King, L. A., King, D. W., Adams, G. A., King, L. A., \& King, D. W. (1996). Relationships Of Job And Family Involvement, Family Social Support, And Work-Family Conflict With Job And Life Satisfaction. 81(4), 411-420. Https://Doi.Org/10.1037/0021-9010.81.4.411

Almasitoh, U. H. (N.D.). Stres Kerja Ditinjau Dari Konflik Peran Ganda Dan Dukungan Sosial Pada Perawat. 8(168), 63-82.

Anggriana, T. M., Margawati, T. M., \& Wardani, S. Y. (2018). Konflik Peran Ganda Pada Dosen Perempuan Ditinjau Dari Dukungan Sosial Keluarga. Counsellia: Jurnal Bimbingan Dan Konseling, 5(1). Https://Doi.Org/10.25273/Counsellia.V5i1.269

Apollo, \& Cahyadi, A. (2012). Konflik Peran Ganda Perempuan Menikah Yang Bekerja Ditinjau Dari Dukungan Sosial Keluarga. Program Studi Psikologi - Fakultas Psikologi Universitas Katolik Widya Mandala Madiun, 02(02), 255-271.

Arfiena, R., Harsono, \& Tri, M. (2013). Pengaruh Konflik Peran Ganda Terhadap Kinerja Pegawai Wanita Dengan Stres Kerja Sebagai Variabel Pemediasi Di Dinas Pendapatan Pengelolaan Keuangan Dan Aset Kabupaten Kulon Progo. Iv No.1, 1-30.

Azwar, S. (2015). Metode Penelitian. Yogyakarta: Pustaka Belajar.

Budijanto, Didik. M. K. Dkk. (2018). Provil Kesehatan Indonesia 2018. Https://Doi.Org/10.1002/Qj

Churiyah, M. (2011). Pengaruh Konflik Peran, Kelelahan Emosional Terhadap Kepuasan Kerja Dan Komitmen Organisasi. Jurnal Ekonomi Bisnis, 2(16), 145-154. Retrieved From Http://Fe.Um.Ac.Id/Wp-Content/Uploads/2009/10/8-Madziatul-Churiyah.Pdf 
Dhania, D. R. (2010). Pengaruh Stres Kerja , Beban Kerja ( Studi Pada Medical Representatif Di Kota Kudus ). I(1), 15-23.

Dwikurniarinidina. (2005). Konco Wingking ". Peranan Perempuan Di Luar Rumah Tangga Dalam Perspektif Historis, 000(2002), 1-16. Retrieved From File:///C:/Users/CACC/Downloads/449011443-1-PB.Pdf

Empati, J., Wijayanti, A. T., \& Indrawati, E. S. (2016). PENYULUH DI KABUPATEN PURBALINGGA. 5(April), 282-286.

Greenhaus, J., \& Beutell, N. J. (1985). Sources Of Conflict Between Work And Family Roles, Academy Of Management Review, Vol. (January 2016). Https://Doi.Org/10.5465/AMR.1985.4277352

Harter, J. K., Schmidt, F. L., \& Keyes, C. L. M. (2004). Well-Being In The Workplace And Its Relationship To Business Outcomes: A Review Of The Gallup Studies. Flourishing: Positive Psychology And The Life Well-Lived., 205-224. Https://Doi.Org/10.1037/10594-009

Hasibuan, Malayu. S. . (2009). Manajemen Sumber Daya Manusia (Edisi Revi). PT Bumi Aksara.

Indriani, D., \& Sugiasih, I. (2016). Dukungan Sosial Dan Konflik Peran Ganda Terhadap Kesejahteraan Psikologis Karyawati Pt . Sc Enterprises Semarang. 11(1), 46-54.

Juwita, K., \& Arintika, D. (2018). Dampak Konflik Peran Terhadap Stres Dan Kepuasan Kerja Karyawan Pt. Jombang Intermedia Press (Jawa Pos Radar Jombang). Jurnal Manajemen Indonesia, 18(2), 105. Https://Doi.Org/10.25124/Jmi.V18i2.1237

Karambut, C. A. (2011). Analisis Pengaruh Kecerdasan Emosional, Stres Kerja Dan Kepuasan Kerja Terhadap Komitmen Organisasional ( Studi Pada Perawat Unit Rawat Inap RS Panti Waluya Malang ). (66).

Kaswan. (2015). Sikap Kerja (Satu; Zulhendri Ferli, Ed.). Bandung: Alfabeta,Cv.

Kenneth N. Wexley, \& Gary A. Yuki. (1992). Perilaku Organisasi Dan Psikologi Personalia (Cetakan Ke). Jakarta: Rineka Cipta.

Lidya Agustina. (2009). Pengaruh Konflik Peran, Ketidakjelasan Peran, Dan Kelebihan Peran Terhadap Kepuasan Kerja Dan Kinerja Auditor. 1(1), 40-69.

Luthans, F. (2006). Perilaku Organisasi (Edisi Sepu). Yogyakarta: PT.Andi.

Mayasari, M. (2014). Analisis Work Family Conflict Terhadap Kesejahteraan Psikologis Pekerja Analisis Work Family Conflict Terhadap Kesejahteraan Psikologis Pekerja. (January).

Nimas Ayu Putri Laksmi, C. H. (2012). Hubungan Antara Konflik Peran Ganda (Work Family Conflict) Dengan Kepuasan Kerja Pada Karyawati Bagian. 1(02), 66-72.

Robert L. Mathis, J. H. J. (2014). Human Resource. In Kybernetes (Vol. 29). Https://Doi.Org/10.1108/K.2000.06729cae.004

Ruslina. (2014). Hubungan Antara Konflik Peran Ganda Dengan Stres Kerja Pada Wanita Bekerja. 
Hubungan Antara Kepuasan Kerja dengan Konflik Peran Ganda Pada Perawat Wanita yang Sudah Menikah di Rumah Sakit Islam Sultan Agung Semarang Vol. 15 (1) 2020, 78-87

Santrock, J. W. (2002). Life - Span Development : Perkembangan Masa Hidup Jilid 1 / John W. Santrock; Alih Bahasa Achmad Chusairi, Juda Damanik. Jakarta : Erlangga.

Strauss, G., \& Leonard Sayles. (1996). Manajemen Personalia Segi Manusia Dalam Organisasi (Jilid 1). USA: Pressindo, Pustaka Binaman.

Sugiyono. (2014). Metode Penelitian Kuantitatif Kualitatif Dan R\&D (20th Ed.). Bandung: Alfabeta,Cv.

Sutrisno Edi. (2009). Manajemen Sumber Daya Manusia Edisi Pertama (Edisi Pert). Jakarta: Kencana Prenada Media Group.

Triono, A. J., \& Prayitno, A. (2017). Pengaruh Konflik Peran Dan Ambiguitas Peran Terhadap Stres Kerja Dan Kinerja Pegawai Dinas Penerangan Jalan Dan Pengelolaan Reklame Kota Semarang. 2(2), 92-100. 